\title{
Mortgage Prepayment by Defeasance
}

\author{
by George Lefcoe
}

\author{
Copyright @ 1999 George Lefcoe
}

To protect against losses when borrowers prepay to take advantage of declining interest rates, banks and insurance companies have come to rely on "yield maintenance" clauses. These provisions require the borrower to make a lump sum payment to cover the lender's potential loss from reinvesting prepaid sums. For reasons described later, yield maintenance provisions have proved woefully insufficient to compensate the holders of securitized commercial mortgage loans when borrowers prepay. Increasingly, mortgage loans originated for sale through commercial mortgage backed securities (CMBS) only allow prepayment through defeasance. Under defeasance provisions, prepaying borrowers must provide Treasury obligations exactly matching the cash flow of all scheduled mortgage payments. This article compares the practical consequences of yield maintenance to defeasance provisions for commercial borrowers and mortgage bond investors.

\section{The Evolution of Yield Maintenance Clauses}

Two decades ago the most common prepayment disincentives in commercial mortgages were capped fees. Among the most popular "capped fee" formulas was "5-4-3-2-1". For prepaying in the first year of the loan, the lender assessed the borrower 5\% of the prepaid sum, $4 \%$ in year two and so forth. Other formulas appeared as well, such as $10 \%$ of the prepaid sum or six month's interest on the prepaid balance above $20 \%$.

Yield maintenance clauses have eclipsed capped fees because capped fees take no account of whether the lender stands to gain or lose from the borrower's prepayment. Gain or loss depends largely on the difference between the prepaying borrower's contract interest rate and the market rate at the time of prepayment. In times of falling interest rates, rational borrowers would prepay as soon as the present value of the borrower's savings exceeded the "capped fee". Predictably, the fee would always fall short of the lender's actual loss on reinvesting prepaid sums. Ironically, although lenders profit when borrowers prepay in times of higher prevailing market, capped fees deter prepayment even then. Correcting this defect, yield maintenance clauses precisely align the borrower's costs of prepayment to the lender's prospective loss on reinvesting prepaid sums.

\section{The Nuances of Yield Maintenance Clauses}

The yield maintenance concept is to assess the borrower a one-time fee sufficient to enable the investor, reinvesting at current rates, to earn what it would have earned had the borrower not prepaid. The fee equals the difference, usually discounted to present value, between the original contract rate and the current market rate multiplied by the amount of the prepayment. 
Yield maintenance clauses differ significantly in their definitions of original yield and current yield. The commercial mortgage promulgated by FNMA and FHLMC overcompensates the lender by defining current yield as the rate on Treasury obligations of comparable maturity to the loan being prepaid and original yield as the note contract rate. The overcompensation derives from Treasury obligations being safer than mortgages, and hence always paying investors less. Yield maintenance clauses avoid overcompensating lenders by using a Treasury rate for both the original and current yields or adding a spread to a Treasury rate in calculating current yield and subtracting that from the original mortgage rate. ${ }^{1}$

Besides reinvestment losses, prepaid mortgagees could incur two additional types of losses: loan processing costs and temporary reductions in interest income while the lender "parks" the funds in low yielding, short term government securities, pending mortgage reinvestment. Most yield maintenance provisions disregard these items, realistically assuming that lenders recoup fully their loan origination costs from borrower fees, and reinvest funds almost instantaneously.

\section{Defeasance}

In the CMBS market, defeasance allows a prepaying borrower to replace a real estate mortgage with a carefully assembled package of noncallable and nonprepayable U.S. government obligations as substitute collateral for the loan. The prepayment option is only available after a two year lock out period, a period of time during which prepayment is absolutely prohibited, to preserve the CMBS status as a REMIC (real estate mortgage investment conduit). ${ }^{2}$

The servicer designated in the CMBS offering reviews the borrower's defeasance request, based on the opinion of a recognized rating agency that the defeasance will not cause a downgrade, qualification, or withdrawal of the then-current ratings on the mortgage certificates.

For borrowers defeasance is worse than yield maintenance for three reasons. First, the borrower is substituting a Treasury obligation for a mortgage, with no commensurate reduction in its loan obligation even though this overcompensates the lender to the extent that investors favor Treasury obligations over mortgages.

Second, under a yield maintenance clause, the borrower pays nothing when the original yield exceeds the current yield. Regardless of the relationship between the original contract rate and prevailing rates at the time of prepayment, the defeasing borrower always incurs the expense of purchasing Treasury obligations.

Third, the cost of organizing a defeasance is considerable. Accumulating a matching set of Treasury obligations is complicated by the fact that mortgage payments usually call for monthly amortization and Treasury obligations do not. Most prepaying mortgagors will require the services of a bond trader. Prepaying borrowers will also be charged by the rating agency for its opinion, the master servicer for its processing fees, a Certified Public Accountant's comfort letter 
that the cash flow from the substituted collateral will meet all scheduled mortgage payments on time, a legal opinion that the borrower has fully complied with all defeasance requirements, and the costs of forming a special purpose entity to act as the successor borrower.

\section{When Commercial Borrowers Prepay}

To predict when commercial borrowers are likely to prepay, imagine a matrix composed of two sets of variables. ${ }^{3}$ The first set depicts market rates either rising or falling from the time the borrower becomes obligated on a fixed rate mortgage loan. The second set shows the value of the security property as rising or falling from the time of the mortgage origination date. The matrix covers four possibilities: (1) interest rates fall, and values increase;(2) interest rates fall, and values decrease; (3) interest rates rise, and values decrease; (4) interest rates rise, and values increase.

Commercial borrowers would be expected to refinance under conditions described in (1) Borrowers would eagerly refinance to generate tax-free cash from a larger loan at lower interest rates. Neither yield maintenance nor defeasance would usually pose insurmountable obstacles under these circumstances.

In the second situation, few commercial borrowers would be positioned to take advantage of declining interest rates by refinancing. The typical commercial loan calls for so little amortization that when the value of the security property has fallen, refinancing proves impracticable. Refinancing would prove an even more remote possibility in the third situation, with increased interest rates adding to the borrower's debt service burden.

Commercial borrowers regularly refinance in situation (4). Consider this example: the borrower, a real estate developer, needs $\$ 5,000,000$ to finance an apartment development. It can borrow $\$ 4$ million on an acquisition, development and construction loan. To obtain the \$1 million shortfall, it will refinance an older project, presently subject to a $\$ 3,000,000$ mortgage, at $7 \%$, despite the fact that current mortgage rates are $9 \%$. Trading a $7 \%$ loan for a $9 \%$ one on $\$ 3,000,000$ increases the developer's interest cost by up to $\$ 60,000$ a year. But the developer accepts the additional interest burden because it anticipates earning a construction fee on the apartment project of $\$ 250,000$, an annual management fee of $\$ 40,000$, and, upon completion, an equity in the new development worth $\$ 2,500,000$.

In situation (4), the developer would be exonerated from having to make any payment under a borrower-friendly yield maintenance formula but would be required to assume the costs of a defeasance. Those costs would be mitigated if interest rates have risen enough so that the borrower could purchase Treasuries for less than the face value of the mortgage balance.

\section{Why Y ield M aintenance Provisions Fail Prepaid M ortgage B ondholders}

Yield maintenance formulas calculated at the loan level are no guarantee that bondholders will be made whole when loans are prepaid, often under or overcompensating particular CM BS bondholders. 
To offer one example, consider a $\$ 50,000,000$ bullet loan, all principal due in 10 years, secured by two twin office towers, each appraised by the lender at $\$ 37,500,000$. The interest rate is fixed at $8 \%$. One day after the loan closes, the borrower receives and accepts an offer of $\$ 45,000,000$ for one of the towers. Providently, the borrower had contracted for the right to prepay $\$ 30$ million of the debt in exchange for a release of the mortgage on one tower.

Under a yield maintenance provision, the borrower's prepayment fee would depend significantly on the precise language of the clause. Suppose the provision defined original yield as $8 \%$ and current yield as a Treasury of like maturity, then trading at $5.5 \%$. The borrower would be liable for $2.5 \%$, the difference between $8 \%$ and $5.5 \%$, multiplied by the prepaid sum, discounted to present value. Had the yield maintenance clause measured original and current yield from the same yardstick-utilizing mortgage or Treasury rates in both instances-the borrower would incur no prepayment fee obligation.

Now consider the position of bondholders if the mortgage loan had been securitized before the partial prepayment. For simplicity, assume the securitization contained only the one underlying mortgage of $\$ 50,000,000$.

The issuer created an A and a B tranche ("tranche" is F rench, for "slice"). The A tranche investor purchased the right to receive the first principal and interest payments, at $7 \%$, on $\$ 30,000,000$. The $B$ tranche investor bought the right to receive the next $\$ 20,000,000$ at $7.7 \%$. Finally, the issuer sold to $C$ an interest only $(I O)$ strip for the one percent premium on the $\mathrm{A}$ tranche -- the difference between the mortgagor's $8 \%$ interest rate and the $\mathrm{A}$ tranche investor's $7 \%$ coupon rate.

C's purchase was especially important to the issuer because, besides fee income, the issuer's profit depends on the spread between the mortgage interest rate and what bond investors receive. The issuer could patiently pocket the difference each month but preferred cash now, as do most issuers.

A gain, assume the mortgagor partially prepaid one day after A, B, and C purchased their respective interests. A will be fully repaid. Because securitized debt is traded at a spread above Treasuries, whether $\mathrm{A}$ can reinvest in a comparable $7 \%$ deal depends on whether Treasury rates, and the spread between Treasuries and mortgage rates, have remained constant. A ssuming no change in these numbers, the A tranche holder will be able to reinvest without loss-- except for transactions costs. Those costs could be more than covered by the borrower's $2.5 \%$ yield maintenance fee. But there would be no source of recovery from a yield maintenance clause precisely calculated to measure the mortgagee's reinvestment loss.

B's situation is enviable. Far from costing B anything, the borrower's prepayment delivers a windfall to B. Before prepayment, B's loan to value (LTV) ratio was $66 \%$. After prepayment, it would improve to $53 \%$. Given that A had accepted $7 \%$ on an LTV of $40 \%$, what would B have rationally accepted? The difference between that rate and $7.7 \%$ is the measure of B's windfall. Anything B recovers from the mortgagor's yield maintenance fee adds to B's windfall. 
C stands to suffer a substantial loss. The mortgagor's obligation to pay interest ceases with prepayment. $\mathrm{C}$ will get nothing, unless the borrower is obligated for a prepayment fee and $\mathrm{C}$ has been given the right to receive it. Of course, knowledgeable purchasers of 10 strips consider prepayment fee allocation formulas, in deciding what they will pay. "There is seemingly no end to the number of ways underwriters can distribute the penalties." ${ }^{4}$

Defeasance saves the CMBS issuer struggling to devise an acceptable formula for allocating yield maintenance payments fairly among competing classes of bondholders by assuring that all the investors in the securitized pool continue receiving their payments on schedule. The cash keeps flowing but from U.S. Treasury obligations, not a mortgage, increasing the value of the investment by the amount by which investors prefer government bonds to mortgages. The only other means of assuring an uninterrupted cash flow is through a lock out, an absolute prohibition against the borrower prepaying for the life of the loan. Clearly, borrowers would prefer defeasance to a life-of-loan lockout. Further, banks and insurance companies will consider substituting defeasance for yield maintenance to preserve the option of securitizing their commercial loans.

George Lefcoe is the Florine and Ervin Yoder Professor of Real Estate Law at the University of Southern California Law School. The author gratefully acknowledges the counsel of Scott L.N. Davidson, Managing Director of CMBS for Chase Securities, Inc. and Laurence G. Preble, partner, O'Melveny \& Myers, and the research assistance of Jason C. Robertson and Raunn Michael Ross.

1.Borrowers have often challenged over compensatory yield maintenance provisions as unlawful liquidated damages, unsuccessfully except in some bankruptcy courts. Compare In re A.J. Lane \& Co., 113 B.R. 821 (D. Mas. 1990) (striking down fee based on 1\% of prepaid balance 
prepayment fee as unreasonable liquidated damage) with In re Schaumburg Hotel Owner Limited Partnership, 97 B.R. 943 (N.D. Ill, , E.D., 1989 ) (upholding fee of 10\% of prepaid sum as reasonable liquidated damage). However, in Schaumburg interest rates had fallen so far that the lender's actual loss was 50\% higher than the contract prepayment charge. W. Barry Blum, The Oversecured Creditor's Right to Enforce a Prepayment Charge as Part of Its Secured Claim Under 11 U.S.C. Section 506(B), 98 COM. L. J. 78 (1993).

2.REMICs are a tax code-authorized entity created to enable mortgage investors to purchase shares of pooled mortgages while avoiding the double taxation of interest income-first at the conduit level, and then on the distribution of interest income to mortgage investors. See generally, Joseph L. Ferst and Milton K. Miyashiro, Federal Income Taxation of REMICs and CMBS in THE HANDBOOK OF MORTGAgE BACKED SECURITIES (Fabozzi and Jacob, 2d ed. 1999) 441.

3.This matrix was suggested by Michael A. Ervolini, Harold A. Haig, and Michael A. Megliola, Credit-Driven Prepayment and Default Analysis, THE HANDBOOK OF COMMERCIAL MoRTGAGEBACKED SECURITIES (2d ed. 1999) ( Frank J. Fabozzi and David P. Jacob, eds, 1999) 265, 270.

4. Manus J. Clancy and Michael Constantino III, The Effects of Prepayment on the Bond Structures of CMBS, in THE HANDBOOK OF COMMERCIAL MORTGAGE-BACKED SECURITIES (Fabiozzi and Jacob eds., 1997) 139, 146. 